
\title{
R Reserach S Suare \\ Isolation and Identification of an Endophytic Bacteria Bacillus sp. K-9 Exhibiting Biocontrol Activity Against Potato Common Scab
}

\author{
Ma Shuang ( $\sim$ ndms1022@163.com ) \\ 0002-2214-0798

\section{Yanjie Wang} \\ Heilongjiang Bayi Agricultural University \\ Wang Teng \\ Heilongjiang Bayi Agricultural University \\ Guanghui Jin \\ Heilongjiang Bayi Agricultural University
}

hei long jiang ba yi nong ken da xue: Heilongjiang Bayi Agricultural University https://orcid.org/0000-

\section{Research Article}

Keywords: Endophytic bacteria, Streptomyces scabies, Potato scab, Biocontrol, Bacillus

Posted Date: February 2nd, 2022

DOI: https://doi.org/10.21203/rs.3.rs-1221321/v1

License: (c) (i) This work is licensed under a Creative Commons Attribution 4.0 International License. Read Full License 


\section{Abstract}

Potato scab is an important soil-borne disease that can significantly reduce the quality and economic value of potatoes. The purpose of this study was to isolate, screen and identify endophytic bacteria that have antagonistic and control effects on potato scab disease, and to determine the control effect and yield traits of the selected strains on potato scab disease in field conditions. A bacterial strain K-9 was isolated from the junction between scab spot and healthy epidermis of potato tuber. The K-9 strain was identified as a new species of Bacillus sp. through morphological, physiological and biochemical characterization, and 16S rDNA and gyrB gene sequence analysis. The diameter of the inhibition zone of strain K-9 against Streptomyces scabies on the YME plate was $3.82 \mathrm{~cm}$. The K-9 strain could inhibit eight types of crop pathogens, with the highest inhibition rate (70.39\%) against another soil-borne potato disease 邓potato black scurfख. In the field test, the control effect of K-9 strain against potato scab was not significantly different from that of mixed bacteria or chemical agents, but the disease index and the scab index in the K-9 treatment were significantly lower than in the control. The potato yield in the K-9 treatment was $12.44 \%$ higher than the control. In summary, the K-9 strain can prevent not only potato scab, but also increase potato yield. Therefore, the endophytic bacterial K-9 strain may be a potential biological control agent.

\section{Introduction}

Potato (Solanum tuberosum L.) is rich in carbohydrates and a variety of minerals and nutrients needed by humans, with high nutritional value and strong adaptability to the environment, and can be widely cultivated in diverse climate conditions (Majeed et al. 2017). Early maturing varieties of potato have a short growth period and can be harvested 60 days after emergence, which can quickly alleviate food shortages caused by diseases and other disasters. Potato plays an important role in economy and global food security (Mario et al. 2019).

The potato industry is developing rapidly because of high nutritional value, strong adaptability and short growth period of potatoes. However, with the rapid development of potato industry, the incidence and severity of scab have been increasing year by year due to the continuous planting of potatoes, which negatively influenced the development of potato industry. Potato scab, as a disease spread by soil and seed potato, is widespread in the potato-growing areas and has become an urgent problem in potato growing industry (Lankau et al. 2020). Potato scab is widely distributed in the world, and has been found in Argentina and other South American countries, the United States, Germany, Mexico, Finland, Japan, and South Korea, as well as in Yunnan, Heilongjiang and Shandong provinces of China (Joshi et al. 2010; Cheng et al. 2019; Leiminger et al. 2013; Ciaghi et al. 2018; Hiltunen et al. 2021; Chater 2016; Sousa et al. 2016). More than 20 species of scab pathogens have been reported, the most common of which are Streptomyces scabies ( $S$. scabies), S. acidiscabies and S. turgidiscabies. S. scabies is the main pathogen responsible for potato scab. It can invade plants through skin cuts, wounds or young tubers, and can infect also other root crops such as radish, beet, carrot, and parsnip (Flores et al. 2010; Santos-Cervantes et al. 2017).

In recent years, potato scab has become one of the main diseases of potato crops in the world. The control of potato scab depends mainly on the large-scale application of chemical pesticides. Although chemical 
agents have certain control effects, environmental pollution and human health problems are becoming increasingly serious. Therefore, researchers began to study biopesticides to control crop diseases. More and more studies have found that endophytic bacteria have potential for biological control of crop diseases (Fu et al. 2018). Endophytic bacteria can resist pathogenic microorganisms or promote plant growth and colonize plants over a long time (Abdallah et al. 2016). The use of endophytic bacteria for the prevention and control of potato scab, potato scab prevention and control effect is stable and lasting. The use of endophytic bacteria to reduce or replace the use of pesticides and fertilizers is of great significance for maintaining the biodiversity of plant microecosystems, maintaining ecological balance and realizing sustainable development.

\section{Materials And Methods}

\section{Pathogens and plant samples}

S. scabies used in this study was isolated from potato common scab disease by our laboratory and purified and cultured in yeast malt agar medium (YME) (yeast extract $4 \mathrm{~g}$, malt extract $10 \mathrm{~g}$, glucose $4 \mathrm{~g}$, sterile water $1000 \mathrm{~mL}, \mathrm{pH}$ 7.2). The cultures were store at $-80^{\circ} \mathrm{C}$. Potato black scurf (Rhizoctonia solani), potato early blight (Alternaria solani), maize leaf spot (Bipolaris zeicola, Curvularia lunata, Alternaria), maize root rot (Fusarium fujikuroI), wheat take-all (Gaeumanomyces graminis), and mung bean anthracnose (Colletotrichum gloeosporioides) were isolated and preserved by plant pathology laboratory of Heilongjiang Bayi Agricultural University. Potato tubers were sampled from Keshan, Longzhen and Jianshan farms in Heilongjiang Province, China.

\section{Isolation and screening of antagonistic strains}

The potato tubers were surface disinfected with $75 \% \mathrm{v} / \mathrm{v}$ ethanol for $30 \mathrm{~s}$ and $5 \% \mathrm{v} / \mathrm{v}$ sodium hypochlorite for $1 \mathrm{~min}$ followed by rinsing with sterile water. A sterile scalpel was used to cut the interface between the diseased potato spot and the healthy potato skin, and ground it in a sterile mortar. The homogenate was placed in a sterile centrifuge tube, diluted with $10 \mathrm{~mL}$ sterile water to $10^{-2}-10^{-6}$, and $100 \mu \mathrm{L}$ of each dilution was spread on a beef extract medium (NA) plate (beef extract $3 \mathrm{~g}$, peptone $5 \mathrm{~g}$, yeast extract $1 \mathrm{~g}$, sucrose 10 $\mathrm{g}$, agar $17 \mathrm{~g}$, sterile water $1000 \mathrm{~mL}, \mathrm{pH} 7.2)$. Sterile water $(100 \mu \mathrm{L})$ of the last rinse was used as control to test whether the surface was thoroughly disinfected (Sun et al. 2003). The isolates were purified and cultured at $28^{\circ} \mathrm{C}$ and stored in at $-80^{\circ} \mathrm{C}$.

Antagonistic strains were screened by the dual culture method (Cui et al. 2019). Streptomyces scabies was cultured on YME plates for $7 \mathrm{~d}$ and then inoculated in YME liquid medium at $30^{\circ} \mathrm{C}, 180 \mathrm{r} / \mathrm{min}$ for $72 \mathrm{~h}$ to prepare the $S$. scabies suspension. The antagonistic bacterial isolates were then inoculated on the YME plates $(85 \mathrm{~mm})$ containing $200 \mu \mathrm{L}$ of $S$. scabies suspension. The plates containing only Streptomyces scabies were used as the control. The inhibition rate of bacterial strains was determined. The antibacterial activity of antagonistic bacteria was evaluated by the diameter of inhibition zone. The strains with the highest rate of inhibitory of $S$. scabies were selected for further study.

\section{Identification of antagonistic strains}


The strain antagonistic to $S$. scabies with the highest bacteriostatic rate were preliminarily identified by morphological characteristics (Jin et al. 2019; Zhang et al. 2017). The antagonistic strains were inoculated on NA medium and cultured at $28^{\circ} \mathrm{C}$ for 3 days. The antagonistic strains were cultured in NA plate for $24 \mathrm{~h}$, then Gram-stained, observed under a microscope, and photographed. The physiological and biochemical properties of the strain were determined by referring to Bergey's Bacteria Identification Manual and Manual of Identification of Common Bacterial Systems (Buchanan et al. 1984; Dong et al. 2001).

The antagonistic bacterium was further identified through the analysis of its 16S rDNA and gyrB gene sequences (Lane, 1991; Yu et al. 2010; La et al. 2004). DNA of antagonistic strains was extracted by a Tiangen Bacterial genome kit. The $16 \mathrm{~S}$ rDNA primers were 27F (5'-AGAGTTTGATCCTGGCTCAG-3') and 1492R (5'-GGTTACCTTGTTACGACTT-3'). The gyrB amplification was performed with the gyrB-F primer (5 'GAAGT CATCATGACCGTTCTGCAYGCNGGNGGNAARTTYGA-3') and gyrB-R(5'-AG CAGGGTACGGATGTGCGAGCCRTCNACRTCNGCRTCNGTCAT-3'). The PCR amplification of 16S rDNA was done in a mix containing PCR MIX $25 \mu \mathrm{L}$, positive and negative primers $1 \mu \mathrm{L}$ each, and bacterial DNA $2 \mu \mathrm{L}$. The PCR reaction procedure was: pre-denaturation at $95^{\circ} \mathrm{C}$ for $5 \mathrm{~min} ; 95^{\circ} \mathrm{C}$ denaturation for $30 \mathrm{~s}$, $62{ }^{\circ} \mathrm{C}$ annealing for $30 \mathrm{~s}, 72{ }^{\circ} \mathrm{C}$ extension for $45 \mathrm{~s}, 30$ cycles; the final elongation was at $72{ }^{\circ} \mathrm{C}$ for $7 \mathrm{~min}$. The products were sequenced by Sangon Biotech Co. Ltd (Shanghai, China). After BLAST comparison on NCBI, strains with high similarity in GenBank (http://blast.ncbi.nlm.nih.gov/Blast.cgi) were selected and the neighbor- joining method in MEGA 7 software was used to construct a phylogenetic tree. The nucleotide sequences were deposited in GenBank database, and the accession numbers were obtained.

\section{Inhibition spectrum of Bacillus sp .strain K-9}

For testing the response of fungal pathogens to Bacillus sp. strain K-9, a 6-mm fungal plug of Rhizoctonia solani, Alternaria solani, Bipolaris zeicola, Curvularia lunata, Fusarium fujikuroi, Gaeumanomyces graminis, and Colletotrichum gloeosporioides were transferred to the center of a potato dextrose agar (PDA) plate. Antagonistic strains were inoculated at the top, bottom, left, and right of the bacterial colonies cultured for 24 $\mathrm{h}$, followed by additional culturing at $28{ }^{\circ} \mathrm{C}$ for 5 days. Petri dishes inoculated with only pathogenic bacteria were used as control, and each treatment was repeated 3 times. The cross-crossing method was used to calculate the bacteriostatic rate.

\section{Effects of K-9 in controlling common scab of potato in field}

The plots infected with potato scab (incidence rate $=100 \%$ ) were used. The total rainfall from April to September was $643 \mathrm{~mm}$, and the average temperature was $15.76{ }^{\circ} \mathrm{C}$. The soil type was chernozem soil, with uniform fertility and level ground. The properties of the soil in the surface layer of $10-30 \mathrm{~cm}$ are shown in Table 1.

Table 1 Physicochemical properties of the soil $(10-30 \mathrm{~cm}$ soil layer) 


\begin{tabular}{|c|c|c|c|c|c|}
\hline $\begin{array}{l}\text { Soil } \\
\text { properties }\end{array}$ & $\begin{array}{l}\text { Alkali-hydrolyzale } \\
\text { nitrogen } \llbracket \mathrm{mg} \cdot \mathrm{kg}^{-1} \text { ) }\end{array}$ & $\begin{array}{l}\text { Available } \\
\text { phosphate } \\
\text { 冈mg } \mathrm{kg}^{-1} \text { ) }\end{array}$ & $\begin{array}{l}\text { Available } \\
\text { potassium } \\
\left.\text { 冈mg } \cdot \mathrm{kg}^{-1}\right)\end{array}$ & $\mathrm{pH}$ & $\begin{array}{l}\text { Organic } \\
\text { matter } \\
\text { }\left(\mathrm{g}^{-1} \mathrm{~kg}^{-1}\right)\end{array}$ \\
\hline Value & $155.25 \pm 0.86$ & $28.62 \pm 0.52$ & $388.5 \pm 4.37$ & $6.12 \pm 0.14$ & $31.52 \pm 0.55$ \\
\hline
\end{tabular}

In this experiment, we used the potato variety 'Eugene' (highly susceptible to disease). Potato scab disease was controlled by antagonistic strain, mixture of bacteria and vernamycin (chemical pesticide). The experiment was sown on May 3, 2021, with precision spot-seeding. The spacing of each hole was $25 \mathrm{~cm}$, and the row spacing was $80 \mathrm{~cm}$. The seedling preservation rate in the field was $98 \%$. The treatments adopted the method of hole application, with antagonistic strain fermentation broth $\left(10^{8} \mathrm{cfu} / \mathrm{mL}\right)$ applied at $50 \mathrm{~mL} / \mathrm{hole}$. The biological agents and chemical pesticides were applied according to the concentration given by producers: eprobiotics $\left(249 \mathrm{~g} / 667 \mathrm{~m}^{2}\right.$, water consumption $\left.166 \mathrm{~L}\right)$ at $50 \mathrm{~mL} /$ hole, vernamycin $(830 \mathrm{~mL} / 667$ $\mathrm{m}^{2}$, water consumption $166 \mathrm{~L}$ ) at $50 \mathrm{~mL} /$ hole. The NA medium was applied at $50 \mathrm{~mL} /$ hole as the control.

The experiment was set up as a completely randomized block design, consisting of four treatments and three replicates, with a total of 12 plots $\left(20 \mathrm{~m}^{2}\right.$ each). A central part $\left(12 \mathrm{~m}^{2}\right)$ of each potato plot was selected to investigate potato yield and disease incidence, disease index, and the control effect at harvest. The severity of disease (grades 1-6) was judged based on the percentage of tuber area with lesions.

Table 2 Grading criteria for potato common scab

\begin{tabular}{lll} 
Disease stage & Representative value & Grading criteria \\
\hline 1 & 0 & No spots on the potato \\
\hline 2 & 1 & Scab spots account for $0-5 \%$ of the potato \\
\hline 3 & 2 & Scab spots account for $5 \%-12.5 \%$ of the potato \\
\hline 4 & 3 & Scab spots account for $12.5 \%-25 \%$ of the potato \\
\hline 5 & 4 & Scab spots account for $25 \%-50 \%$ of the potato \\
\hline 6 & 5 & Scab spots account for $50 \%$ of the potato
\end{tabular}

The formula used in this section is as follows(Li Cuiping.2021):Yield $\left(\mathrm{kg} / \mathrm{hm}^{2}\right)=$ measured yield $/$ measured yield area $\times 10000 \mathrm{~m}^{2}$; Yield increase effect $=$ (treatment yield - control yield $) /$ control yield $\times 100 \%$; Disease index $=\left\{\left[\sum\right.\right.$ (number of diseased potatoes at each level $\times$ representative value at each level) $] /$ (number of total potato investigated $\times$ highest representative value) $\} \times 100$; Control efficiency $=[$ (disease index of control area - disease index of treatment area)/ disease index of control area] $\times 100 \%$; Scab index $=$ [mean grade of lesion area $(\mathrm{MA}) \times$ mean grade of lesion depth $(\mathrm{MD})] / 20 \times 100 \%$.

\section{Statistical analysis}

Statistical analysis was performed using SPSS software(IBM SPSS Statistics, Version 22.0, International Business Machines Corporation, New York, in USA). Mean values were compared using Duncan's new 
multiple range test at the $1 \%(P<0.01)$ level of significance between treatments.

\section{Results}

\section{Isolation and screening of antagonistic bacteria}

According to their morphological characteristics, 73 strains of endophytic bacteria were isolated from potato tubers, purified and stored at $-80^{\circ} \mathrm{C}$. The antagonistic activity to $S$. scabies was screened by the double culture method. Twelve endophytic bacteria showed antagonistic activity to S.scabies. The diameter of inhibition zone ranged from 1.97 to $3.82 \mathrm{~cm}$ (Table 3). The maximum antibacterial diameter of strain $\mathrm{K}-9$ was $3.82 \mathrm{~cm}$, and the antibacterial rate of strain K-9 was $44.90 \%$. When screened in fermentation broth, the strain K-9 had the antibacterial rate of $53.92 \%$ (Fig. 1).

Table 3 Bacteriostasis zones of potato isolated bacteria against Streptomyces scabies

\begin{tabular}{ll} 
Strains & The diameters of inhibition zones $\varangle \mathrm{cm} \nabla$ \\
\hline CK & 0 \\
\hline $1(\mathrm{~L})$ & $2.90 \pm 0.08 \mathrm{cC}$ \\
\hline $2(\mathrm{~L})$ & $1.97 \pm 0.02 \mathrm{aA}$ \\
\hline $3(\mathrm{~L})$ & $2.89 \pm 0.14 \mathrm{cC}$ \\
\hline $4(\mathrm{~J})$ & $3.37 \pm 0.12 \mathrm{cC}$ \\
\hline $5(\mathrm{~J})$ & $2.93 \pm 0.08 \mathrm{deD}$ \\
\hline $6(\mathrm{~K})$ & $3.41 \pm 0.14 \mathrm{bB}$ \\
\hline $7(\mathrm{~J})$ & $2.55 \pm 0.04 \mathrm{bB}$ \\
\hline $8(\mathrm{~L})$ & $2.60 \pm 0.07 \mathrm{dD}$ \\
\hline $9(\mathrm{~K})$ & $3.82 \pm 0.17 \mathrm{fE}$ \\
\hline $10(\mathrm{~J})$ & $3.60 \pm 0.04 \mathrm{eDE}$ \\
\hline $11(\mathrm{~K})$ & $2.83 \pm 0.12 \mathrm{cBC}$ \\
\hline $12(\mathrm{~K})$ & $3.40 \pm 0.04 \mathrm{deD}$
\end{tabular}

Data are mean \pm standard error. Different letters mean significantly different according to Duncan's multiple range test $(P<0.05$ and $P<0.01)$. CK:Streptomyces scabies $\square L$ Heilongjiang Longzhen, J Heilongjiang Jianshan, $K$ Heilongjiang Keshan, $9(\mathrm{~K}): \mathrm{K}-9$ strain.

\section{Morphological characterization of antagonistic strain}

The colony of strain K-9 was round or oval, white, opaque, with uneven surface, regular edge, and no pigment production (Fig. 2-a,b). Under a light microscope, K-9 bacteria were rod-shaped and Gram-positive (Fig. 2-c). 


\section{Physiological and biochemical characterization of antagonistic strain}

The results of physiological and biochemical identification showed that strain K-9 was Gram-positive and produced hydrogen sulfide gas during metabolism. Strain K-9 decomposed starch and gelatin. Citric acid and phenylalanine deaminase reactions were negative. Nitrate reduction, indole, V-P, and MR reactions were positive. The strain could grow normally on LB medium containing $1-10 \% \mathrm{w} / \mathrm{v} \mathrm{NaCl}$ (Table 4). According to the physiological and biochemical tests, and combined with morphological characteristics, according to the handbook of Systematic Identification of Common Bacteria and Berger Handbook of Identification of Bacteria, the strain was preliminarily identified as Bacteriaceae, Firmicutes, Bacida, Bacillus, Bacillus, Bacillus genus.

Table 4 Physiological and biochemical characteristics of strain K-9

\begin{tabular}{|llll|}
\hline Test index & Result & Test index & Result \\
\hline Gram staining & + & MR & - \\
\hline $\mathrm{pH} 10$ & + & $5 \% \mathrm{Nacl}$ & + \\
\hline $\mathrm{V}-\mathrm{P}$ & + & $7 \% \mathrm{Nacl}$ & + \\
\hline Contact Enzyme & + & $10 \% \mathrm{Nacl}$ & + \\
\hline Starch hydrolysis & + & Phenylalanine amino acid deaminase & - \\
\hline Nitrate & + & Ammonia production test & + \\
\hline Indole test & + & Gelatin Liquefaction & + \\
\hline Citrate & - & Hydrogen sulfide test & + \\
\hline
\end{tabular}

Note: +: Positive; -: Negative

\section{Genomic identification of antagonistic strain}

The length of 16S rDNA of strain K-9 was $1447 \mathrm{bp}$. The GenBank accession numbers of the 16S rDNA gene sequence and the gyrB sequence of strain K-9 are OL378201 and PRJNA796832, respectively. The 16S rDNA gene sequence of strain K-9 was related to Bacillus velezensis, Bacillus amyloliquefaciens and Bacillus subtilis and other strains, sharing more than $97 \%$ of the genetic sequences. The results of phylogenetic tree showed that K-9 and Bacillus sp. SA3 strain branched closely, with $63 \%$ similarity rate, but Bacillus sp. SA3 strain was only identified at the genus level.

It was difficult to distinguish the types of strain K-9 (Fig. 3). The length of gyrB gene sequence of strain K-9 was $1189 \mathrm{bp}$. BLAST comparison found that the gyrB sequence of K-9 was $99 \%$ similar to that of Bacillus velezensis strain FJAT-52631. The K-9 was closely related also to Bacillus velezensis strain FJAT-52631, but did not cluster together, with similarity rate of $70 \%$ (Fig.4).

\section{Inhibition spectrum of antagonistic strain}


Strain K-9 had significant inhibitory effect on eight crop pathogens (Fig. 5, Table 5). The strongest inhibitory effect was against Rhizoctonia solani (70.39\%) and Colletotrichum gloeosporioides (70\%), and these two inhibition rates were significantly higher than against other pathogens $(P<0.01)$. The inhibition rate of strain K-9 against the pathogenic bacteria (Bipolaris zeicola, Curvularia lunata and Alternaria) in maize leaves was more than $58 \%$. The inhibition rate of strain K-9 against Gaeumanomyces graminis was $46.41 \%$. In summary, strain K-9 had a broad spectrum of antimicrobial activity, indicating a great potential in biocontrol.

Table 5 Inhibition rate of strain K-9 against crop pathogens

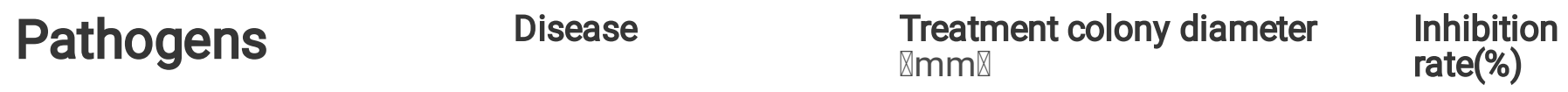

\begin{tabular}{llll}
\hline Rhizoctonia solani & Potato black scurf & $25.17 \pm 0.96 \mathrm{aA}$ & $70.39 \pm 1.13 \mathrm{cC}$ \\
\hline Alternaria solani & Potato early blight & $30.17 \pm 1.12 \mathrm{bB}$ & $50.55 \pm 3.96 \mathrm{aA}$ \\
\hline Bipolaris zeicola & Maize leaf spot & $34.58 \pm 1.71 \mathrm{cC}$ & $59.31 \pm 2.01 \mathrm{bB}$ \\
\hline Curvularia lunata & Maize leaf spot & $26.33 \pm 1.25 \mathrm{aA}$ & $60.35 \pm 1.83 \mathrm{bB}$ \\
\hline Alternaria & Maize leaf spot & $26.00 \pm 1.27 \mathrm{aA}$ & $58.40 \pm 1.91 \mathrm{bB}$ \\
\hline F.fujikuroi & Maize root rot & $24.08 \pm 0.24 \mathrm{aA}$ & $49.83 \pm 1.58 \mathrm{aA}$ \\
\hline Gaeumanomyces graminis & Wheat take-all & $25.50 \pm 0.41 \mathrm{aA}$ & $46.41 \pm 2.55 \mathrm{aA}$ \\
\hline $\begin{array}{l}\text { Colletotrichum } \\
\text { gloeosporioides }\end{array}$ & $\begin{array}{l}\text { Mung bean } \\
\text { anthracnose }\end{array}$ & $24.17 \pm 0.59 \mathrm{aA}$ & $70.04 \pm 0.66 \mathrm{cC}$
\end{tabular}

Data are mean \pm standard error. Different letters mean significantly different according to Duncan's multiple range test $(P<0.05$ and $P<0.01)$.

Inhibition rate $(\%)=[($ diameter of the pathogen in control - diameter of the pathogen in treatment $) /$ diameter of the pathogen in control] $\times 100$

\section{Antagonistic efficacy of strain K-9 against potato scab in the field}

The complex microbial inoculant, rapamycin and strain K-9 treatments had no significant effect on potato yield, with the percentage of large potatoes $54.05-60.81 \%$, and the percentage of commodity tubers 82.69 $88.56 \%$ (Table 6). The yield of rapamycin treatment was lower than that of the control, but the percentage of large tubers and commercial tubers was higher than that of the control. The yield of complex microbial inoculant and strain $\mathrm{K}-9$ treatment was $7.03 \%$ and $12.44 \%$ higher than control, respectively. The percentage of large tubers was $1.4 \%$ higher in the treatment with complex microbial inoculant compared with the control, whereas the strain $\mathrm{K}-9$ was associated with a $8.2 \%$ increase in the yield compared with the control. The rate of commercial tubers was lower in the treatment with complex microbial inoculant than the control, but in the treatment with strain $\mathrm{K}-9$ it was $5.4 \%$ higher than the control. The results showed that the strain $\mathrm{K}-9$ treatment could increase potato yield and the percentages of large and commercial-size tubers, thus resulting in an economic benefit of potato planting under the same conditions. 
Table 6 Application in planting hole of strains K-9 on potato yield, large potato and commercial potato percentage

\begin{tabular}{|c|c|c|c|c|c|}
\hline Treatment & $\begin{array}{l}\text { yield per } \\
\text { plot } \varangle \mathrm{kg} / 12 \mathrm{~m}^{2} \square\end{array}$ & $\begin{array}{l}\text { Equivalent } \\
\text { yield } \\
\text { 『kg/hm² }\end{array}$ & $\begin{array}{l}\text { Increase } \\
\text { yield } \% \bigotimes\end{array}$ & $\begin{array}{l}\text { Large } \\
\text { potato } \\
\text { percentage } \\
\square \% \bigotimes\end{array}$ & $\begin{array}{l}\text { Commercial } \\
\text { potato } \\
\text { percentage } \\
\otimes \% \bigotimes\end{array}$ \\
\hline $\begin{array}{l}\text { Control } \\
\text { (NA medium166L/667m²) }\end{array}$ & $38.89 \pm 3.16 a$ & 32422.65 & - & $52.61 \pm 0.08 a$ & $83.15 \pm 1.23 a$ \\
\hline $\begin{array}{l}\text { Mixed bacteria } \\
\varangle 249 \mathrm{~g} / 667 \mathrm{~m}^{2} \square\end{array}$ & $41.83 \pm 1.29 a$ & 34873.65 & 7.03 & $54.05 \pm 0.04 a$ & $82.69 \pm 4.84 a$ \\
\hline $\begin{array}{l}\text { Rapamycin } \\
\left(830 \mathrm{ml} / 667 \mathrm{~m}^{2}\right)\end{array}$ & $37.43 \pm 2.50 a$ & 31205.4 & -3.98 & $56.97 \pm 0.13 a$ & $87.59 \pm 5.18 a$ \\
\hline $\begin{array}{l}\text { Strain K-9 } \\
{\left[16.5 \mathrm{~L}\left(10^{9} \mathrm{CFU} / \mathrm{mL}\right) / 667 \mathrm{~m}^{2}\right]}\end{array}$ & $43.73 \pm 2.33 a$ & 36457.65 & 12.44 & $60.81 \pm 0.14 a$ & $88.56 \pm 3.22 a$ \\
\hline
\end{tabular}

Data are means \pm standard errors. Different letters indicate significant differences according to the Duncan's multiple range test $(P<0.05)$.

Yield $(\mathrm{kg} / \mathrm{ha})=$ measured yield $/$ measured yield area $\times 10000$; Increase in yield $=[($ yield of treatment area yield of control area)/yield of control area] $\times 100 \%$

The field efficacy assessments showed that the treatments with mixed bacteria, rapamycin and strain K-9 had a control effect on potato scab. The disease and scab indices of all three treatments were significantly lower than those in the control (Fig. 6, Table 7). The potato treated with rapamycin had the lowest disease incidence and the control effect was $35.27 \%$, which was not significantly different from the other two treatments, but the scab index was higher in the rapamycin compared with the K-9 treatment (i.e., the spots were deeper in the rapamycin than the K-9 treatment). The disease and scab indices in the complex microbial inoculant treatment were higher than in the K-9 treatment (i.e., the area and depth of potato tuber disease spots were larger in the mixed bacteria treatment than in the K-9 treatment). Taken together, the results on yield, disease index, control effect, and scab index indicated the strain K-9 can be used as a biopesticide to control potato scab.

Table 7 Application in planting hole of strains K-9 field efficacy evaluation of antagonistic against potato scab 


\begin{tabular}{|c|c|c|c|}
\hline Treatment & Disease index $\% \square$ & Control effıciency $₫ \% \rrbracket$ & Scab index(MSI) \\
\hline $\begin{array}{l}\text { Control } \\
\text { (NA medium166L/667m²) }\end{array}$ & $68.98 \pm 0.007 a A$ & - & $25.26 \pm 3.52 \mathrm{aA}$ \\
\hline $\begin{array}{l}\text { Mixed bacteria } \\
\otimes 249 \mathrm{~g} / 667 \mathrm{~m}^{2} \square\end{array}$ & $47.36 \pm 0.019 b B$ & $31.34 \pm 1.09 a \mathrm{~A}$ & $19.03 \pm 2.22 \mathrm{bAB}$ \\
\hline $\begin{array}{l}\text { Rapamycin } \\
\left(830 \mathrm{ml} / 667 \mathrm{~m}^{2}\right)\end{array}$ & $44.65 \pm 0.017 \mathrm{bB}$ & $35.27 \pm 0.87 a A$ & $16.72 \pm 2.06 \mathrm{bB}$ \\
\hline $\begin{array}{l}\text { Strain } \mathrm{K}-9 \\
{\left[16.5 \mathrm{~L}\left(10^{9} \mathrm{CFU} / \mathrm{mL}\right) / 667 \mathrm{~m}^{2}\right]}\end{array}$ & $46.20 \pm 0.009 b B$ & $33.01 \pm 0.96 \mathrm{aA}$ & $14.95 \pm 1.07 \mathrm{bB}$ \\
\hline
\end{tabular}

Data are mean \pm standard error. Different letters mean significantly different according to Duncan's multiple range test $(P<0.05$ and $P<0.01)$.

Disease index $=\left\{\left[\sum\right.\right.$ (number of diseased potatoes at each level $\times$ representative value at each level) $] /$ (number of total potato investigated $\times$ highest representative value) $\} \times 100$; Control efficiency $=[$ (disease index of control area - disease index of treatment area)/ disease index of control area] $\times 100 \%$; Scab index $=$ [mean grade of lesion area (MA) $\times$ mean grade of lesion depth $(M D)] / 20 \times 100 \%$.

\section{Discussion}

After pathogen scab infects potato tubers, forming flat, raised or sunken brown corkification spots on the tuber surface; they affect the commercial value and storage resistance, resulting in a $20 \%-40 \%$ reduction in price and considerable economic losses. Potato scab has restricted the sustainable development of potato industry (especially the seed potato industry). Under the premise of ensuring environmental safety and balanced development of agro-ecosystems, the best way to control potato scab is by changing soil microenvironment and enriching beneficial bacteria on the tuber surface. With that in mind, we applied beneficial bacteria to potato soil holes in order to increase the abundance of beneficial bacteria, reduce the accumulation of pathogenic bacteria and reduce the incidence of scab.

In this study, 73 endophytic strains of potato were isolated from the junction of diseased spot and healthy epidermis of potato tuber, and 12 strains had antagonistic effect on potato common scab. Among them, strain K-9 had the largest inhibition zone against potato common scab pathogen, with the inhibition zone diameter of $3.82 \mathrm{~cm}$ and the inhibition rate of $44.90 \%$. The results showed that endophytic bacteria antagonistic to pathogen could be isolated from the junction of diseased spot and healthy epidermis of potato tuber. This is consistent with some previous similar studies. Iranian researchers isolated endophytic bacteria (Bacillus atrophaeus DM6120 strain) from strawberry roots to inhibit anthrax, with an inhibition rate 
of $54.92 \%$ (Zahra et al. 2021). Researchers in India isolated 14 strains of bacterial endophytes from rice. Among them S3 strain (Bacillus polymyxis) showed good antibacterial activity against Fusarium oxysporum, Pythium aphanidermatum, Phytophthora infestans, and other pathogens (Radhakrishnan et al. 2021).

In this study, the 16S rDNA and the gyrB gene of strain K-9 were amplified. The specific taxonomic status of strain K-9 was not determined completely by phylogenetic analysis due to the complexity of the genome, and strain K-9 was defined as a new species of Bacillus. The entire genome sequence is currently being analyzed to shed more light on the classification of strain K-9. The double culture experiment showed that strain K-9 had antimicrobial effects not only on Streptomyces scabies, but also on other pathogens, such as Rhizoctonia solani, Alternaria solani, Bipolaris zeicola, Curvularia lunata, Fusarium fujikuroi, Gaeumanomyces graminis, and Colletotrichum gloeosporioides. Hence, the strain K-9 has a potential application value in biological control. This study demonstrated the control effect of this antagonistic bacterium on potato scab in the field as well. In this experiment, only the double culture experiment with the eight crop pathogens listed above was carried out in the laboratory, without field control evaluation. Hence, further work on the control effects against these eight crop pathogens in the field is warranted.

- Field control effects of biocontrol agents are affected by environmental conditions, application methods and colonization (Cui et al. 2019). In order to further understand the biocontrol effect of strain K-9 on potato scab, we applied it to the field plots with a long history of scab occurrence. The morbidity in the untreated plots was $100 \%$. In this study, the control effect of strain K-9 on variety 'Eugene' (highly susceptible to potato scab) was $33.01 \%$. The control effect of the complex microbial inoculant and rapamycin treatments was $31.34 \%$ and $35.27 \%$, respectively. There were no significant differences among the three treatments. In the literature, there are many reports on the biological control of potato scab. For example, the control effect of Streptomyces PBSH9 strain in the 1-year field experiment in China using the moderately susceptible potato variety 'Atlantic ocean' reached $47.64 \%$ and the yield increased by $9.7 \%$ (Zhang et al. 2020). The control effect of Bacillus sp. sunhua strain on potato scab in a pot experiment was 53.33\% (Han et al. 2005). In the study presented here, the infection rate in all treatments in the field was $100 \%$, with the plants seriously diseased. Under such environmental conditions, the disease and scab indices of the strain K-9 treatment were significantly lower than those of the control treatment. The yield in the treatment with strain K-9 was $12.44 \%$ higher than that of the control, and the percentage of large tubers and commercial tubers was also higher than in the control, indicating that strain K-9 had a good growth-promoting effect. It was confirmed that the screened endophytic bacterium K-9 could be used as a biological agent to control potato scab disease. This study is the first report of a new species of Bacillus controlling potato scab disease.

\section{Conclusion}

The strain K-9 isolated from the junction of diseased and healthy epidermis of potato has a good control effect against potato scab and also increases yield. The strain K-9 had inhibitory effects on potato common scab pathogen and eight crop pathogenic fungi. In this study, the control effect was shown only in one field experiment with continuous potato cultivation, and there was only one highly susceptible variety of potato tested. Therefore, multi-location and multi-variety trials with strain $\mathrm{K}-9$ should be used to evaluate the control

Page $11 / 18$ 
effect in field. Further study on the inhibition of potato scab by the bacterial strain K-9 and the underlying mechanism is needed before the biological control capacity of the strain can be ascertained.

\section{Declarations}

Funding This research was supported by The Integrated Research and Demonstration of Potato Fertilizer and Pesticide Reduction Technology of the National Researchand Development Program of China(2018YFD020080706).

\section{Compliance with ethical standards}

Conflict of interest The authors declare that they have no conficts of interest.

\section{References}

1. Abdallah RAB, Mokni-Tlili S, Nefzi A, Jabnoun KH, Daami-Remadi M(2016) Biocontrol of Fusarium wilt and growth promotion of tomato plants using endophytic bacteria isolated from Nicotianaglauca organs. Biological Control 97(10):80-88. http:// dx. doi. org/ 10.1016/ j. biocontrol.2016.03.005

2. Andrade MHML, Niederheitmann M, Paula Ribeiro SRR(2019). Development and validation of a standard area diagram to assess common scab in potato tubers. Eur J Plant Pathol 154:739-750. https://doi.org/10.1007/s10658-019-01697-z

3. Buchanan RE, Gibbons NE(1984)Bergey's Bacteria Identification Manual. 8th ed. Beijing: Science Press.DOl:10.1007/bergeysoutline200405

4. Bolivar AHJ, González RVE,Cantoral JM(2021) Endophytic Bacteria Bacillus subtilis, Isolated from Zea mays, as Potential Biocontrol Agent against Botrytis cinerea. Biology 10(6):1-26. http://dx.doi.org/10.3390/biology 10060492

5. Cheng Z, Bown L, Piercey B, Bignell DR (2019) Positive and negative regulation of the virulenceassociated coronafacoyl phytotoxin in the potato common scab pathogen streptomyces scabies. Molecular Plant-Microbe Interactions32:331-356.

6. http:// doi.org /10.1094/MPMI-03-19-0070-R

7. Chater KF (2016). Recent advances in understanding streptomyces. F1000 Research 5:2795. http://doi.org/10.12688/f1000research.9534.1

8. Cui LX, Yang CD, Wei LJ, Li TH, Chen X (2019) Isolation and identification of an endophytic bacteria bacillus velezensis 8-4 exhibiting biocontrol activity against potato scab. Biological Control 141:1-20. http://doi.org/10.1016/j.biocontrol.2019.104156

9. Cui L, Sun Z, Sun F, Yuan J, Tian HX, Wang LQ, XU HY (2003) Isolation of endophytic bacteria from potato and selection of antagonistic bacteria to potato ring rot disease.Acta Phytopathologica Sinica 33:353-358. https://doi.org/10.13926/j.cnki.apps.2003.04.014

10. Dong XZ, Cai MY (2001)Manual of identification of common bacterial systems. Beijing: Science Press. http://www.uzzf.com/soft/185540.html 
11. Fu B Z, Zhu J Q, Wei L N(2018) Antagonism of walnut endophytic bacteria XHE8 against pathogenic fungi and its impact on seed germination. Genomics and Applied Biology 37(04):15061510.http://dx.doi.org/10.13417/j.gab.037.001506

12. Flores GR, Velasco I, Montes(2010) Detection and characterization of streptomyces causing potato common scab in western europe. Plant Pathology 57(1),162-169.https://doi.org/ 10.1111/j.13653059.2007.01734.x

13. Guo-Hui YU, Niu CY, Chen YF, Chen YH, Yang ZH( 2010) Use of $16 \mathrm{~S}$ rDNA, gyrA and gyrB gene sequence to identify a biocontrol Bacillus sp. strain R31. Chinese Journal of Biological Control 26:160-166. https://doi.org/10.1097/MOP.0b013e3283423f35

14. Hiltunen LH, Tarvainen O, Kelloniemi J, Tanskanen J, Karhu J, Valkonen JPT(2021) Soil bacterial community in potato tuberosphere following repeated applications of a common scab suppressive antagonist. Applied Soil Ecology 167:1-11.https://doi.org/10.1016/j.apsoil.2021. 104096

15. Han JS, Cheng JH, Yoon TM, Song J, Suh JW (2010) Biological control agent of common scab disease by antagonistic strain bacillus sp. sunhua. Journal of Applied Microbiology 99:213-221. http://doi.org/10.1111/j.1365-2672.2005.02614.x

16. Joshi MV, Mann SG, Antelmann H, Widdick DA, Fyans JK, Chandra G, Hutchings MI, Tothl, Hecker M, Loria $\mathrm{R}(2010)$ The twin arginine protein transport pathway exports multiple virulence proteins in the plant pathogen streptomyces scabies. Molecular Microbiology 77: 252-271. https://doi.org/10.1111/j.1365-2958.2010.07206.x

17. Jin M, Li S, Tian W, Yang C, Wang Y(2019) Screening, identification and detection of growth-promoting antagonistic endophytic bacteria from carex moorcroftii in alpine grassland. Journal of Plant Protection 46:779-786.https://doi.org/10.13802/j.cnki.zwbhxb. 2019.2018141

18. Lankau EW, Xue D, Chrisensen R, Gevens AJ, Lankau RA(2020) Management and soil conditions influence common scab severity on potato tubers via indirect effects on soil microbial communities. Phytopathology, 110:1-32. https://doi.org/10.1094/ PHYTO- 06-19 - 0223-R

19. Lane, D. J. 16S/23S rRNA sequencing. Nucleic Acid Techniques in Bacterial Systematics, 1991, 115175.DOI: $10.4135 / 9781446279281 . n 7$

20. Li Cuiping, Shi Wencong, Wu Di, Tian Renmao, Wang Bing, Lin Rongshan, Gao Zheng(2021) Biocontrol of potato common scab by Brevibacillus laterosporus BL12 is related to the reduction of pathogen and changes in soil bacterial community. Biological Control 153:104496104508.https://doi.org/10.1016/j.biocontrol.2020.104496

21. La Duc MT, Satomi M, Agata N, Venkateswaran K (2004) gyrB as a phylogenetic discriminator for members of the Bacillus anthracis-Cereus-thuringiensis group. Journal of Microbiological Methods 56:383-394. https://doi.org/10.1016/j.mimet.2003.11.004

22. Majeed A, Muhammad Z, Ullah Z, Ullah R, Ahmad H (2017) Late blight of potato(Phytophthora infestans) I: fungicides application and associated challenges. Food Science and Technology 5:261266. https://doi.org/10.24925/turjaf.v5i3.261-266.1038

23. Radhakrishnan NAR, Joseph BJ(2021) Phenazine 1-carboxylic acid producing seed harbored endophytic bacteria from cultivated rice variety of Kerala and its broad range antagonism to diverse.Plant 
Pathogens pp:1-8.https://doi.org/10.1007/S12602-021-09844-X

24. Stefan C, Sigrid N, Arne S (2018) Draft genome resource for the potato powdery scab pathogen spongospora subterranea. Molecular Plant-Microbe Interactions 31:112-124. http://doi.org/10.1094/MPMI-06-18-0163-A

25. Sousa, JADJ, Olivares FL (2016) Plant growth promotion by streptomycetes: ecophysiology, mechanisms and applications. Chemical and Biological Technologies in Agriculture 3:24. https://doi.org/10.1186/s40538-016-0073-5

26. Santos-Cervantes ME, Felix-Gastelum R, Herrera-Rodríguez G, Espinoza-Mancillas MG, Mora-Romero AG, Leyva-López NE(2017) Characterization, pathogenicity and chemical control of Streptomyces acidiscabies associated to potato common scab.American Journal of Potato Research 94:14-25. https://doi.org/10.1007/s12230-016-9541-5

27. Zhang X, Li C, Hao J, Li Y, Liang Y (2020) A novel streptomyces sp. strain PBSH9 for controlling potato common scab caused by streptomyces galilaeus. Plant Disease 104:15-52. https://doi.org/10.1094/PDIS-07-19-1469-RE

28. Zhang X. Zhou Y Y, Li Y, Fu X C, Wang Q(2017) Screening and characterization of endophytic Bacillus for biocontrol of grapevine downy mildew. Crop Protection 96:173-179.

https://doi.org/10.1016/j.cropro.2017.02.018

29. Zahra Alijani, Jahanshir Amini, Morahem Ashengroph, Bahman Bahramnejad, Ali Akbar Mozafari, (2021) Biocontrol of strawberry anthracnose disease caused by Colletotrichum nymphaeae using Bacillus atrophaeus strain DM6120 with multiple mechanisms. Tropical Plant Pathology.https://doi.org/10.1007/S40858-021-00477-7

\section{Figures}




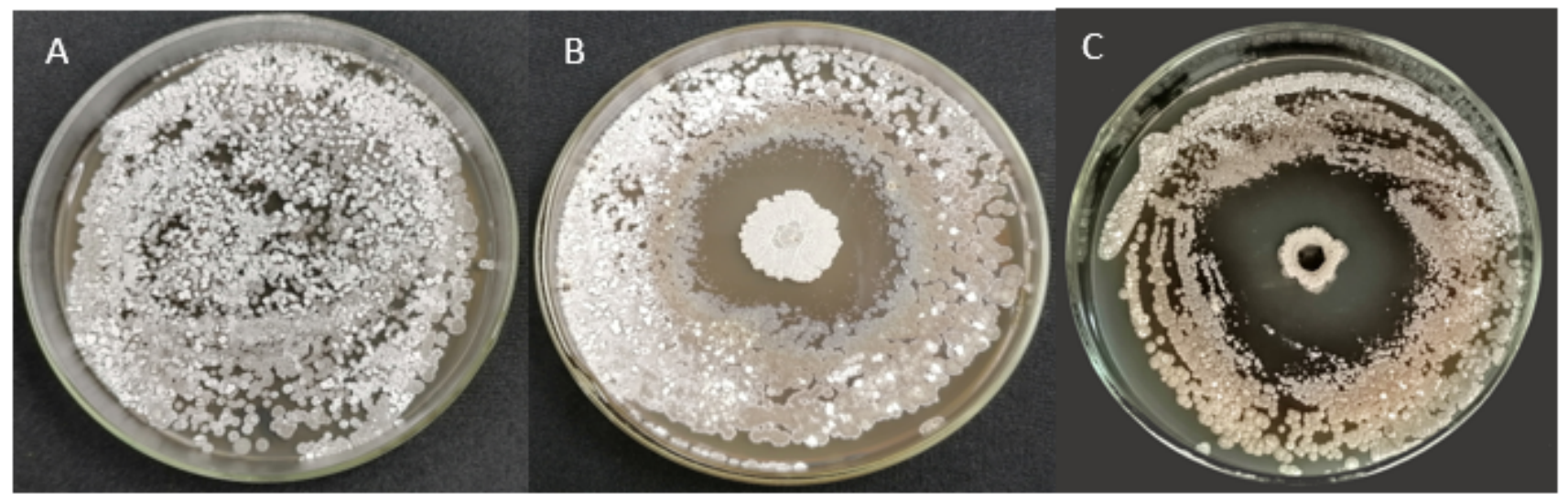

D

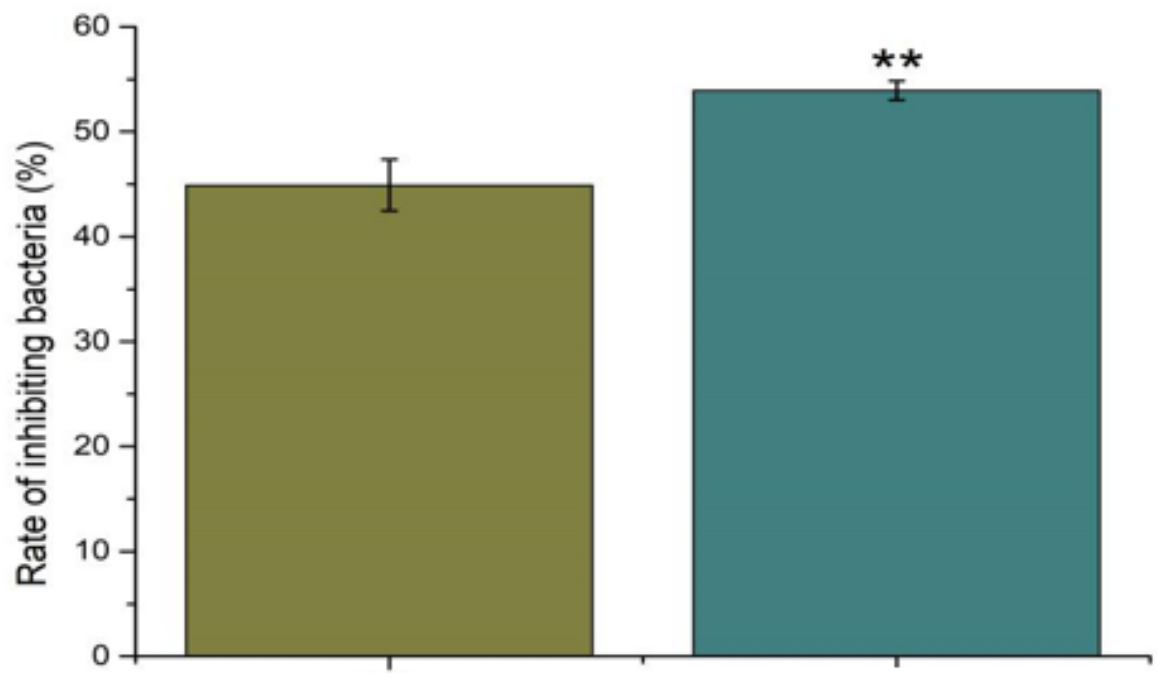

Stain

Fermentation liquor

\section{Figure 1}

Antimicrobial activity of strain K-9 and fermentation broth against Streptomyces scabies

A, B, C, D: Control of S.scabies, Dual-culture of strain K-9 against S.scabies, Strain K-9 ferm-

entation liquid against S. scabies, Bacteriostatic ratio

**: Different letters mean significantly different according to Duncan's multiple range test $(P<0.01)$. 


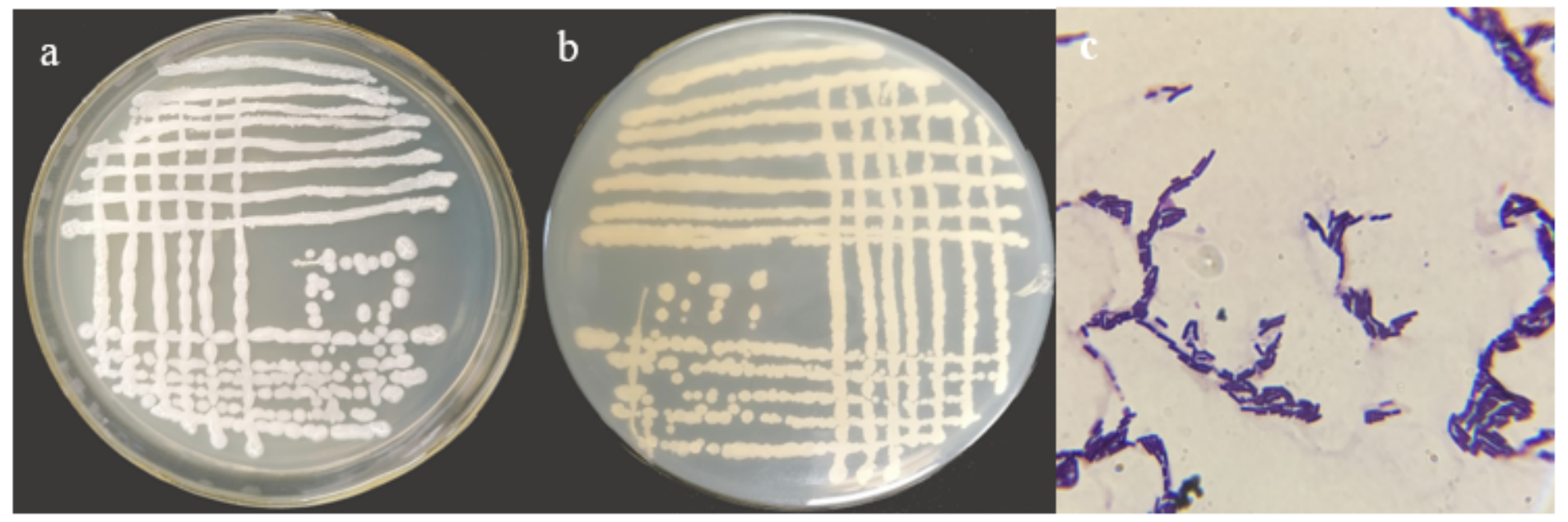

Figure 2

Colony morphology and gram staining of strain K-9

a,b: Colony morphology of strain K-9 on NA plate c: Gram staining of strain K-9(100× magnifica- tion)

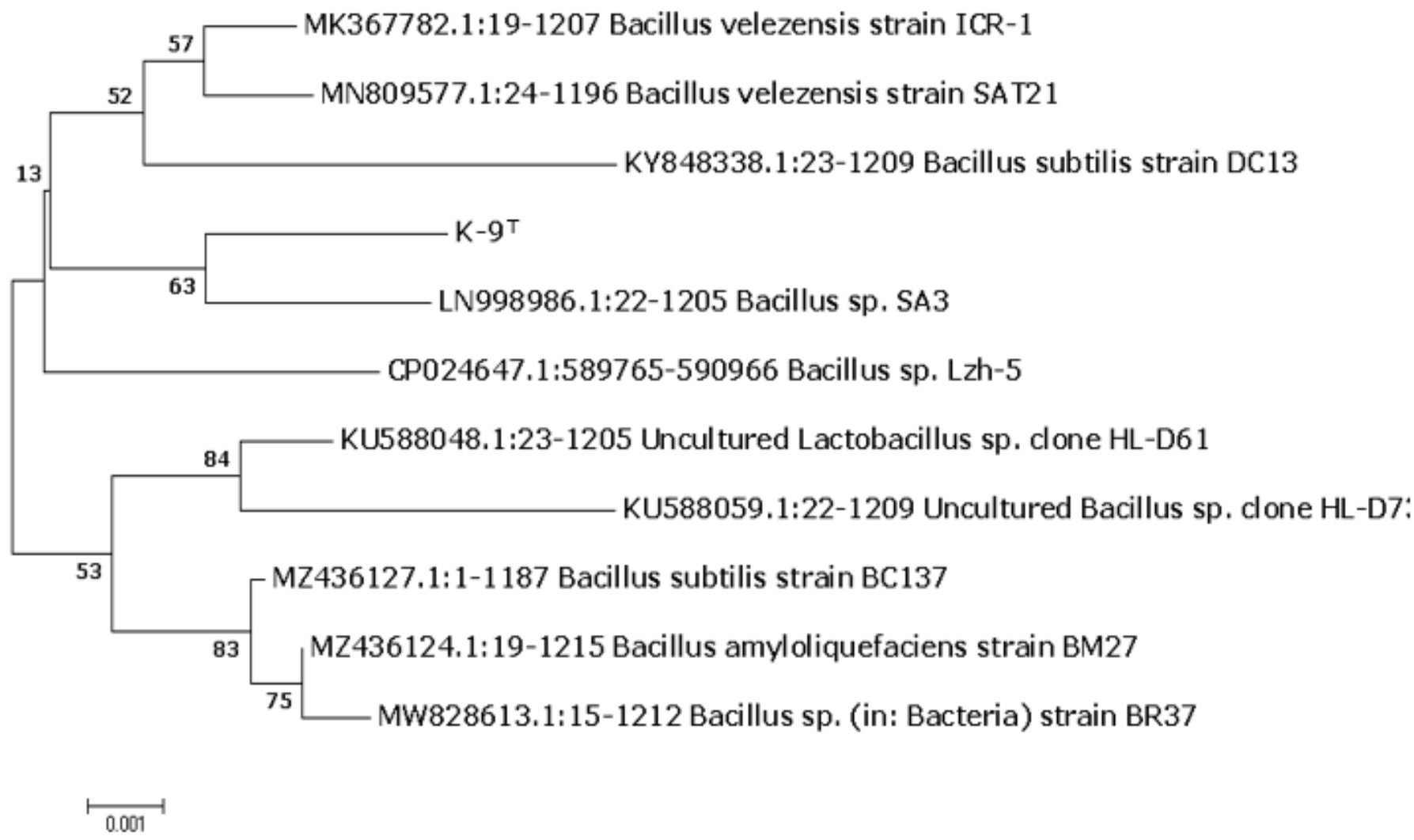

Figure 3

Phylogenetic tree of strain K-9 constructed based on 16S rDNA gene sequence

Bootstrap values (\%) presented at the branches were calculated from 1000 replications. The scale bar means $0.1 \%$ sequence difference. 


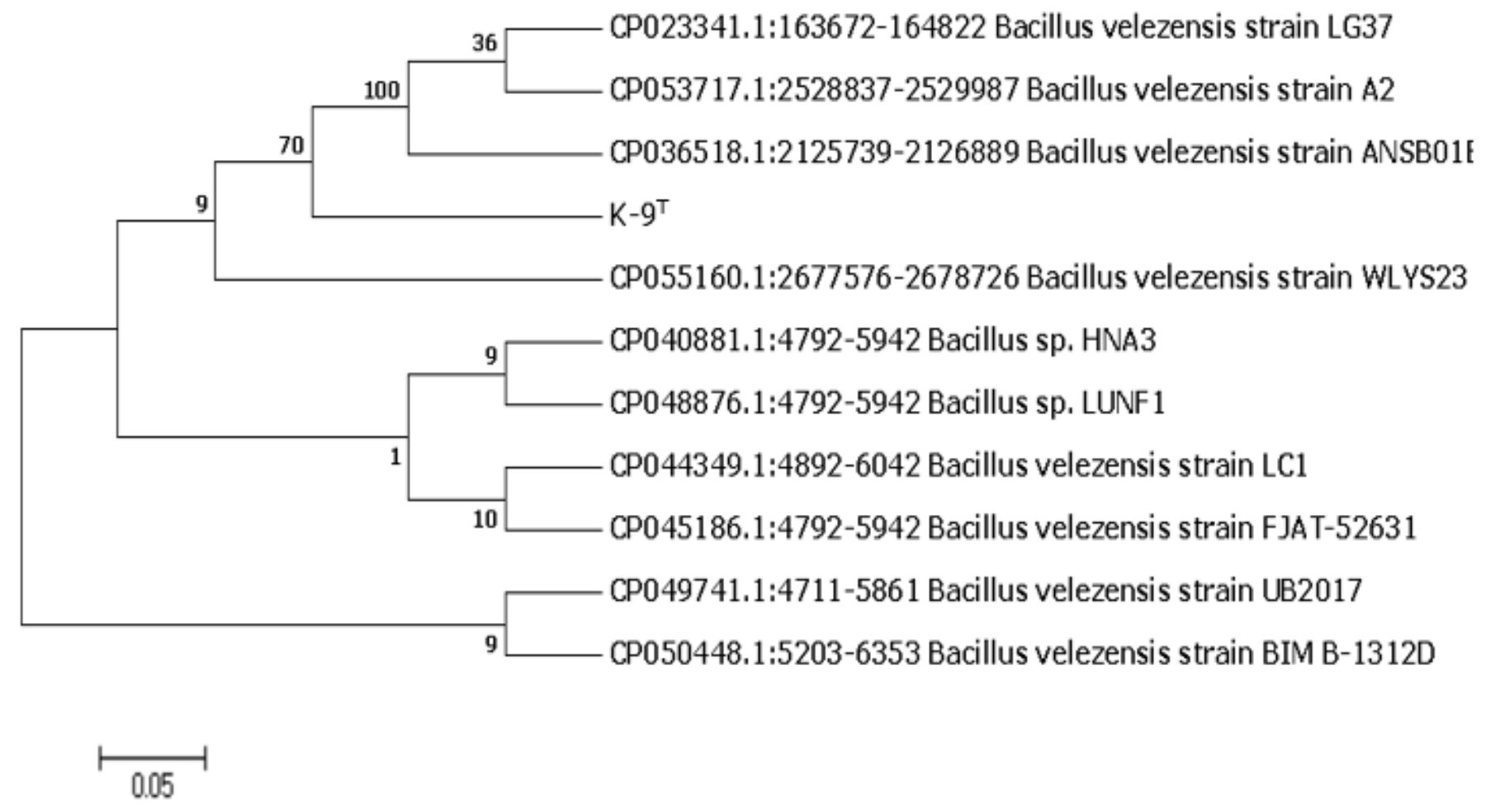

\section{Figure 4}

Phylogenetic tree of strain K-9constructed based on gyrB gene sequence

Bootstrap values (\%) presented at the branches were calculated from 1000 replications. The scale bar means $5 \%$ sequence difference. 


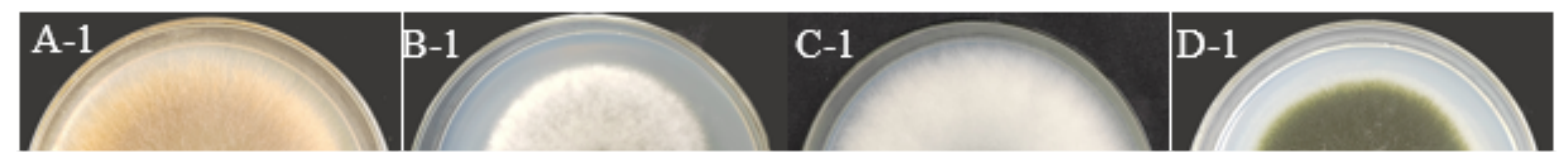

\section{Figure 5}

Determination of antibacterial spectrum of strain K-9

A:Rhizoctonia solani B:Alternaria solani C:Bipolaris zeicola D:Curvularia lunata E: Alternaria F:F.fujikuroi G: Gaeumanomyces graminis $\mathrm{H}$ :Colletotrichum gloeosporioides

-1 : Control of pathogenic fungus -2:Dual-culture of strain K-9 against pathogenic fungus

\section{Figure 6}

Determination of field control effect of strain K-9

A:Control B:Mixed bacteria C:Rapamycin D: Strain K-9 